\title{
Urease activity and deposition of calcium carbonate layers on a 16th century Mughal monument
}

\author{
M. Singh* \\ National Museum Institute, Department of Conservation, Janpath, New Delhi 110 011, India
}

In the present study, bacterial populations capable of re-precipitating calcium carbonate were isolated from the exterior oozed-out calcite deposition of Salabat Khan Tomb, a 16th-century Mughal monument in western India. The deposits were analysed for identification of the materials that led to microbial induced calcite precipitation (MICP) on the surface of the monument. Quantification of MICP by XRD and visualization by SEM showed direct involvement of these isolates in the precipitation of calcium carbonate. FTIR spectra showed clear peaks for calcite along with a peak of methane probably due to dead bacterial cells. Preliminary examination, isolation and partial sequencing of 16S rRNA gene showed that the major microbial population participating in calcite precipitation is heterotrophic and includes mainly Bacillus sp., Arthobacter sp., Agromyces indicus and Aquamicrobium sp. In future, the process may be applied for the conservation of many limestone/ marble monuments using MICP in India and elsewhere.

Keywords: Ancient monuments, bacterial populations, calcium carbonate, microbial-induced calcite precipitation.

ONE of the most relevant examples of mineralization that can be traced back to the Precambrian period is the precipitation of calcium carbonate. Both abiotic changes (physico-chemical factors) and biotic changes (microbial action) participate in the natural precipitation of calcium carbonate. The autotrophic and heterotrophic bacteria, including sulphur, photosynthetic and nitrogen-fixing bacteria which hydrolyses urea and cellulose participate in calcium precipitation. Under favourable conditions, most of these bacteria can produce calcite ${ }^{1}$. The mechanisms by which bacteria precipitate carbonates are still unclear. The precipitation of calcium carbonate can occur through several different pathways ${ }^{2,3}$. Calcium ion concentration, $\mathrm{pH}$ and the presence of nucleation sites control the chemical precipitation of calcium carbonate ${ }^{4}$. In microbial calcium carbonate precipitation, bacteria themselves

\footnotetext{
*e-mail: m_singh_asi@yahoo.com
}

behave as nucleation sites in which calcium ions bind to microbial cell surfaces ${ }^{5}$. When these surfaces become saturated with calcium ions, the ions begin to aggregate, thus initiating the first urease crystalline nuclei which then grow from these structures ${ }^{6}$.

From the role of $\mathrm{Ca}^{2+}$ on urease activity, a ten-fold increase is observed in the presence of $30 \mu \mathrm{m} \mathrm{Ca}^{2+}$ than in the absence of $\mathrm{Ca}^{2+}$ for certain isolates ${ }^{4}$. The precipitation rate of $\mathrm{CaCO}_{3}$ obeys the first or second order of kinetics which is, in general, a linear function of $\mathrm{Ca}^{2+}$ and $\mathrm{CO}^{3-}$ concentration products, where one of the reactants is in excess. Supersaturation of the solution is reached when the concentration of $\mathrm{Ca}^{2+}$ and $\mathrm{CO}_{3}^{2-}$ exceeds the solubility product leading to precipitation of calcium carbonate. Due to the enzymatic urea hydrolysis, it is possible that individual microorganisms produce ammonia to create an alkaline microenvironment around the cell. The high $\mathrm{pH}$ of the localized area does not result in an initial increase in $\mathrm{pH}$ of the entire medium, but brings about growth of $\mathrm{CaCO}_{3}$ crystals around the cell. The possible biochemical reaction in urea- $\mathrm{CaCl}_{2}$ medium can be summarized as

$$
\begin{aligned}
& \mathrm{Ca}^{2+}+\text { cell } \rightarrow \text { cell }-\mathrm{Ca}^{2+}, \\
& \mathrm{Cl}^{-}+\mathrm{HCO}_{3}^{-}+\mathrm{NH}_{3} \leftrightarrow \mathrm{NH}_{4} \mathrm{Cl}+\mathrm{CO}_{3}^{2-}, \\
& \mathrm{Cell}-\mathrm{Ca}^{2+}+\mathrm{CO}_{3}^{2+} \rightarrow \text { cell }-\mathrm{CaCO}_{3} .
\end{aligned}
$$

An alkaline $\mathrm{pH}$ is the primary source through which the microbes promote precipitation of calcium carbonate ${ }^{2,7}$. Different effects of minerals on urease activity have been proposed $^{8}$ with some of them showing contradiction in results. With the addition of $\mathrm{Ni}^{2+}$ in the growth medium of Escherichia coli, an increase in the precipitation of calcium carbonate has been observed ${ }^{9}$. It is reported that $\mathrm{CaCO}_{3}$ precipitation increases considerably by the addition of $\mathrm{Ni}^{2+}$ ions $(5-100 \mu \mathrm{m})$. The role of $\mathrm{Ni}^{2+}$ on urease activity was also confirmed by some other researchers ${ }^{10}$. Previous studies have also demonstrated the effect of heterotrophic bacteria actinomycetes, on the formation of specific speleothems (mineral growths in caves, e.g.

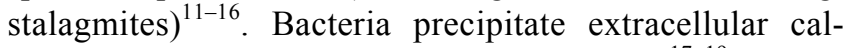
cium carbonate through a variety of processes ${ }^{17-19}$. 


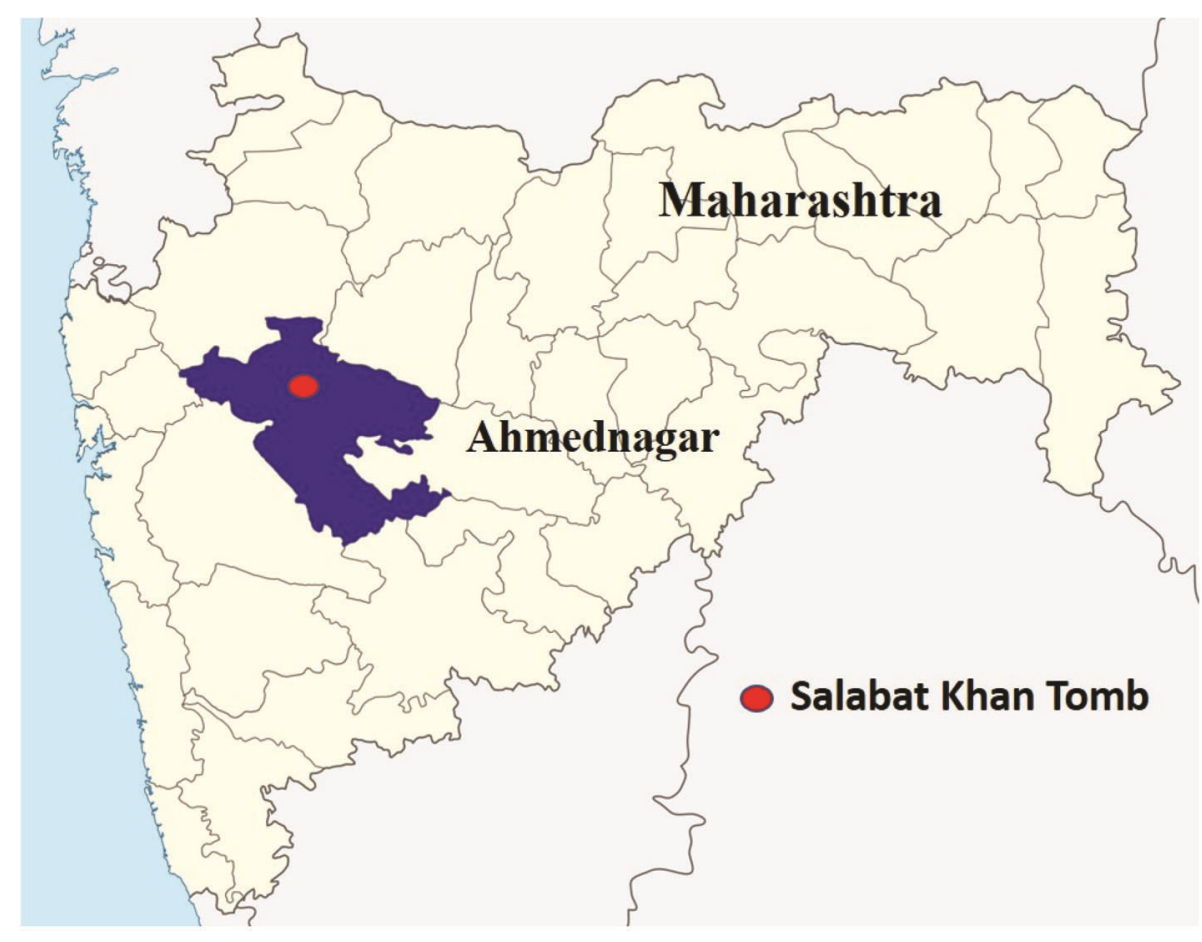

Figure 1. Map showing the location of the Salabat Khan Tomb, Ahmednagar, India.

The first mineralization occurs as a by-product of microbial metabolism that involves either autotrophic pathways which can deplete $\mathrm{CO}_{2}$ locally or heterotrophic pathways which release it into the environment ${ }^{2,20}$. In these mechanisms, enzymatic hydrolysis of urea and the ammonification of amino acids can increase the $\mathrm{pH}$ which, if free $\mathrm{Ca}^{2+}$ is present, results in the precipitation of calcium carbonate. In the second mineralization due to ion exchange, carbonate nucleation takes place on the bacterial cell wall through the cell membrane by poorly understood mechanisms ${ }^{20}$. Mineralization may also occur through the adsorption of divalent cations into specific negatively charged functional groups on the cell wall ${ }^{6}$. Nevertheless, the cell acts as a nucleation site once carbonate has begun to precipitate on the cell surface. This stage is demanding in initiating mineral precipitation; consequently $\mathrm{CaCO}_{3}$ precipitation may be purely inorganic.

The third possibility involves unique proteins present in the extracellular polymeric substances (EPS) produced by bacterial communities that can trap sediments and are often essential for direct deposition of microbial carbonate ${ }^{21,22}$. Formation of bacterial calcium carbonate through urea hydrolysis is known as bacterial calcite precipitation (BCP). It is pollution-free and a natural phenomenon. The major application of BCP is in the removal of contaminants from wastewater, protection and restoration of limestone monuments, formation of sacrificial patina on limestone and production of biological mortar, plugging of pores of oil reservoir, etc. Carbonate stones (for example, limestone and marble) are particular- ly susceptible to weathering because of their composition and textural characteristics, leading to increased porosity and decrease in mechanical strength and cohesion ${ }^{23}$. For monument conservation, the modern trend is to preserve the original stone structure without any chemical coating and minimal human activity. In all cases of stone weathering, water transfer within porous stone is a common problem. With the aim to modify some of the stone surface characteristics, many conservation treatments have been applied in order to decrease susceptibility to decay. Mainly, water repellants are used on the stone surface to prevent the entry of water and other weathering agents. Indeed, water-repellant resins polymerize on porous stone resulting in film formation on stone surfaces. In some cases the resin polymerizes inside the pores, thus completely filling them $\mathrm{up}^{24}$. As preventing water intrusion into porous stone is crucial, it is also significant to maintain gaseous exchange between the stone and the environment ${ }^{25}$. Hence, human action should be restrained to limiting water penetration while allowing bidirectional gaseous transfer.

To meet these criteria, a bio-mineralization treatment as an alternative process was developed on the basis of the ability of bacteria to induce calcium carbonate precipitation $^{26}$. The process to develop biological mortars and patina on limestone is now successful ${ }^{3}$. This method involves spraying bacteria on the entire surface of limestone and subsequently providing nutritional medium containing calcium and urea. By this process, a protective surface coating of $\mathrm{CaCO}_{3}$ (several microns thickness) is formed. For the first time bio-coating was successfully 


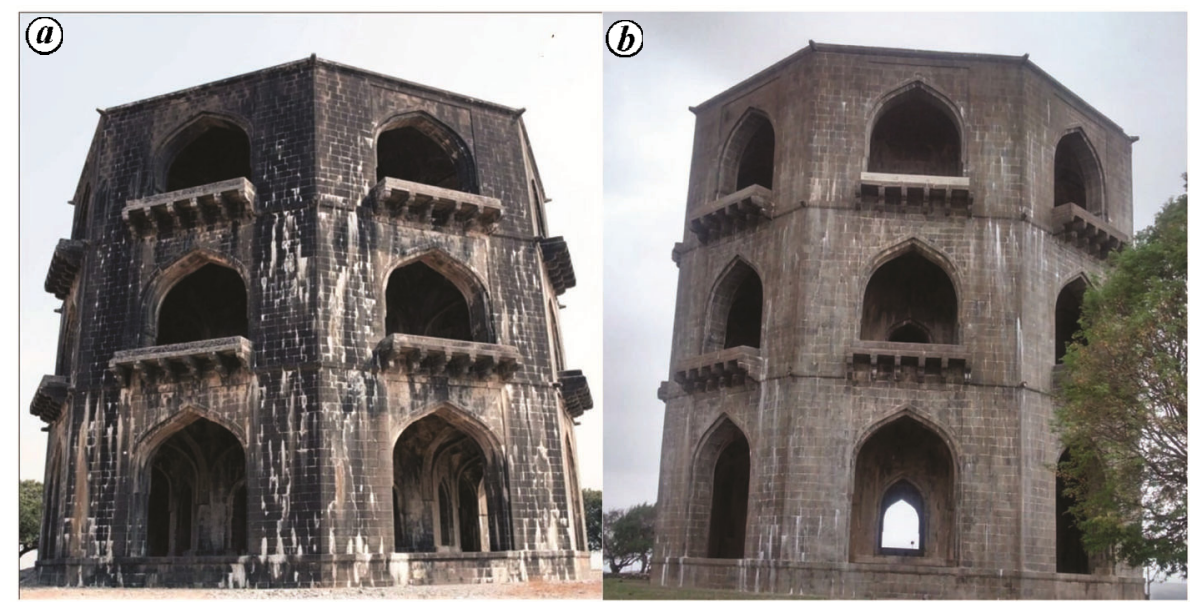

Figure 2. $\boldsymbol{a}$, General view of the Salabat Khan Tomb. $\boldsymbol{b}$, The tomb after removal of calcite concretions.

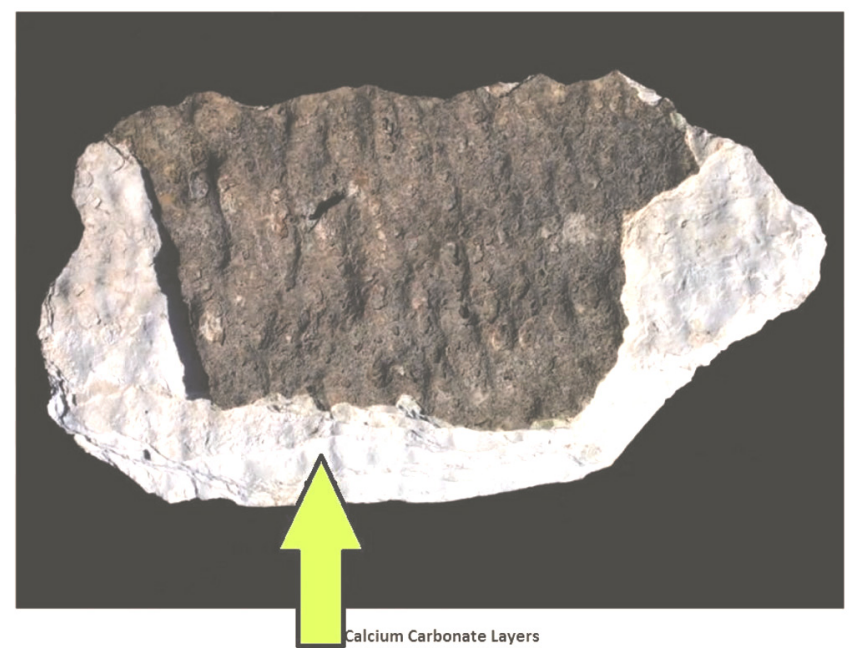

Figure 3. A large calcite concretion showing the stratified layers of deposition.

experimented on a surface area of 50 sq. $\mathrm{m}$ on the southeast tower of the Thouars Church, France ${ }^{27}$. Since then, this treatment is being applied on various buildings and houses in Paris and other parts of France. In India, many such crack remediation programmes have been successfully completed through the bacterial process to reinforce strength and durability of concrete ${ }^{28,29}$. The technique has also been successfully used in the field of geotechnical engineering.

Although a geotechnical revolution is being witnessed with the help of bio-cementation, the process is not suitable in case of the 16th-century Mughal monument in the Deccan plateau of western India, viz. Salabat Khan Tomb, located about $125 \mathrm{~km}$ from the historic city of Aurangabad, Maharashtra, and lying between 182 and $199 \mathrm{~N}$ lat, 739 and $755 \mathrm{E}$ long, situated partly in the Bhima basin and partly in the upper Godavari basin, the interfluves in between forming the extensive Ahmednagar plateau (Figure 1). Figure $2 a$ shows the general view of the tomb. The Salabat Khan Tomb is situated at a hilltop on an average elevation of $900 \mathrm{~m}$ amsl. Constructed with black basalt, the foundation of the tomb has been laid on a circular path, but the monument is octagonal in shape with the height of tomb being $80 \mathrm{ft}$. High-speed wind lashes the monument during all seasons and the tomb is surrounded by windmills on the nearby hilltops all around.

The major conservation problem of this monument is the leaching of binding materials from within the constructed wall during rainy season when rainwater seeps through the roof of the tomb. These leached-out lime-based materials oozes out through the basalt stone joints and flow down to get deposited at the immediate surrounding stone surfaces all around the monument. However, the upper part of the monument shows scarce deposits of leached-out materials probably due to flow of water down with force. The deposited materials can be clearly marked on the outer stone surface of the monument (Figure $2 a$ ). A close inspection provides a clear view of various layers deposited during alternate rainy seasons (Figure 3). Here, bacterial activity results in hardening of deposits and cementing of the layers to make a hard mass, thus masking the aesthetic presentation of the monument. At many points, the exterior surface of the deposits is contaminated due to deposition of dust, dirt and other accretionary materials from the surroundings. On account of hardening of calcite, physiochemical methods have to be employed for the effective removal of deposits from the stone surface.

In the present study, calcite deposits were analysed for their chemical composition, petrological behaviour, and mechanical characteristics. Further by culturing microorganisms under controlled laboratory conditions, it is possible to define their ability to alter the chemistry of their microenvironment and produce biominerals. We used laboratory-based cultures to examine the extent to which heterotrophic calcifying bacteria are effective in 
RESEARCH ARTICLES

Table 1. Chemical composition (\% weight) of the Interior lime and calcite deposits

\begin{tabular}{lccccc}
\hline Oxides & $\begin{array}{c}\text { Sample 1 } \\
\text { (interior lime core) }\end{array}$ & $\begin{array}{c}\text { Sample 2 } \\
\text { (calcite deposit) }\end{array}$ & $\begin{array}{c}\text { Sample 3 } \\
\text { (calcite deposit) }\end{array}$ & $\begin{array}{c}\text { Sample 4 } \\
\text { (calcite deposit) }\end{array}$ & $\begin{array}{c}\text { Sample 5 } \\
\text { (calcite deposit) }\end{array}$ \\
\hline $\mathrm{Na}_{2} \mathrm{O}$ & 0.00 & 2.85 & 3.90 & 3.5 & 3.1 \\
$\mathrm{~K}_{2} \mathrm{O}$ & 0.00 & 1.02 & 0.57 & 0.89 & 0.74 \\
$\mathrm{MgO}$ & 8.65 & 0.76 & 1.22 & 1.04 & 0.5 \\
$\mathrm{CaO}$ & 75.83 & 87.28 & 88.07 & 87.87 & 88.16 \\
$\mathrm{Al}_{2} \mathrm{O}_{3}$ & 8.73 & 0.00 & 0.65 & 0.35 & 0.14 \\
$\mathrm{SiO}_{2}$ & 2.46 & 0.89 & 0.55 & 0.72 & 0.65 \\
$\mathrm{Fe}_{2} \mathrm{O}_{3}$ & 2.90 & 0.77 & 0.52 & 0.65 & 0.42 \\
$\mathrm{MnO}^{\mathrm{ZnO}}$ & 0.00 & 0.57 & 0.33 & 0.54 & 0.36 \\
$\mathrm{SeO}_{3}$ & 0.00 & 1.41 & 0.30 & 1.30 & 0.62 \\
$\mathrm{CuO}$ & 0.00 & 1.10 & 0.00 & 0.82 & 0.85 \\
$\mathrm{P}_{2} \mathrm{O}_{5}$ & 1.43 & 2.71 & 2.97 & 2.48 & 1.23 \\
\hline
\end{tabular}

Table 2. Minerals present in the sample

\begin{tabular}{lcl}
\hline Sample no. & Major mineral & Minor minerals \\
\hline 1 & Calcite & Quartz, biotite \\
2 & Calcite & Quartz, biotite \\
3 & Calcite & Quartz, biotite \\
4 & Calcite & Quartz, biotite \\
\hline
\end{tabular}

calcite deposition. Instrumental techniques such as FTIR, XRD and SEM were used for characterization of calcite. The present study outlines the role of bacteria in hardening the calcite deposits of Salabat Khan Tomb, which is aesthetically unsuitable for this monument. However, the technique can be applied successfully in the conservation of many limestone/marble monuments.

\section{Materials and methods}

\section{Chemical characterization}

As the monument is sound and structurally compact, it is not possible to obtain samples of the inner lime core for analysis without causing damage to the structure. Therefore, from a small aperture present on a damaged hole on the first floor, few milligrams of the sample was collected and subjected to chemical and petrological analysis. We could only collect one lime core sample for which analytical study was carried. Four samples from exterior calcite deposits collected from all sides of the monument were subjected to chemical and petrological analysis. Besides, four samples of exterior calcite deposits were also removed mechanically from all the sides and immediately packed in sterilized air container for carrying out detailed studies using FTIR, SEM, mechanical properties and microbial analysis in the laboratory.

X-ray fluorescence (Philips 1410, holland) set-up was used to determine the chemical composition of the samples. Sample 1 in this analysis represents the lime core and samples 2-5, the deposited and hardened calcite patches on the exterior surfaces of the basaltic stone monument. Table 1 shows the results of the chemical analysis.

\section{Petrological analysis}

Samples 1-4 were also observed under a petrological microscope for their mineral content (Table 2). Calcite was the major mineral present in the sample while very small quantities of quartz and biotite were also seen. For petrological analysis, condense polarized light microscope (Carl Zeiss JENA POL) was used. The sample was also analysed by heating a known weight of the sample at $105^{\circ} \mathrm{C}, 400^{\circ} \mathrm{C}$ and $900^{\circ} \mathrm{C}$ to determine the water vapour, organic matter and carbon dioxide content.

\section{Collection, isolation, crystallization and initial urea analysis using $16 \mathrm{~S}$ rRNA gene sequencing}

Sample collection: The samples for microbial analysis were collected from the monument using sterile swabs. The exterior flora was wiped by swabs grown in the laboratory. Air flora was collected by exposing a sterile medium plate in air.

The internal flora of calcium deposits was isolated using a sterile needle. The needle was inserted in the calcium deposits and then inoculated in the sterile broth medium.

The large fragments of calcium sample were broken in a laminar air-flow hood. The outer covering of the solution which was contaminated due to deposition of dust and dirt from the environment was carefully removed and inner part of the sample was suspended in soybean casein digest medium. Then the medium was incubated at room temperature for five days.

The typical colonies were maintained on soybean casein digest agar slants. These selected colonies were then 


\section{RESEARCH ARTICLES}

inoculated in soybean casein digest medium with calcium acetate. The flask was incubated at room temperature for five days and then observed for precipitation. Figure 4 shows turbidity in the flask after the aforesaid process.

After incubation, serial dilutions were made from $10^{-1}$ to $10^{-10}$ using $0.9 \%$ saline, and $0.1 \mathrm{ml}$ of each dilution plated on precipitation medium containing $3 \mathrm{~g}$ nutrient broth, $20 \mathrm{~g}$ urea, $2.12 \mathrm{~g} \mathrm{NaHCO}_{3}, 10 \mathrm{~g} \mathrm{NH}_{4} \mathrm{Cl}$ and $30 \mathrm{mM}$ $\mathrm{CaCl}_{2} \cdot \mathrm{H}_{2} \mathrm{O}$. The plates were incubated at room temperature for five days. After incubation, the total viable count was also determined. The specific colonies were selected for microbial identification of bacterial isolates based on 16S rRNA gene sequencing. The typical colonies were maintained on the above-mentioned medium.

Isolation: The isolated strains were introduced into sterile conical flask containing $100 \mathrm{ml}$ of nutrient broth followed by incubation at $37^{\circ} \mathrm{C}$ overnight and subjected to plating on nutrient agar plates with appropriate dilution. The colonies were assessed once in every 5 days with the help of a stereomicroscope and positive colonies were chosen based on the formation of visual crystals within 10 days. Positive colonies isolated was purified by repetitive dilution and plating (Figure $5 a$ and $b$ ). Four isolates, viz. S1-S4 were chosen and the above cultures were preserved on Luria agar slants till further use.

PCR amplification of $16 S$ rRNA gene: A DNA template for PCR amplification from pure cultures was obtained by extracting total genomic DNA using Axy Prep Bacterial Genomic DNA Miniprep Kit, following the manual instructions, and its purity and quantification were accomplished by Nanodrop spectrophotometer (Thermo, USA). The PCR master mixture contained each primer at a concentration of $500 \mathrm{nM}$, each deoxynucleotide

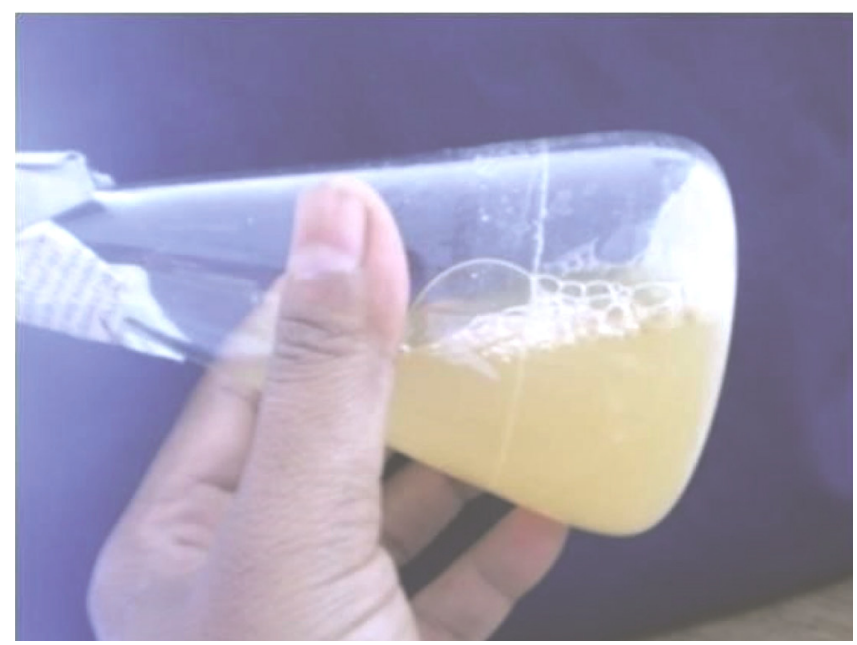

Figure 4. Sample of calcite incubated in nutrient broth. triphosphate at a concentration of $200 \mu \mathrm{M}, 15 \mathrm{mM}$ $\mathrm{MgCl}_{2}, 10 \mu \mathrm{l}$ of thermophilic DNA polymerase (sigma), $400 \mathrm{ng} / \mu \mathrm{l}$ of bovine serum albumin (Boehringer) and addition of DNAase and RNAase free sterilized water making a final volume of $100 \mu \mathrm{l}$. Next, $1 \mu \mathrm{l}$ DNA template was added to $24 \mu \mathrm{l}$ of master mixture. The $16 \mathrm{~S}$ rRNA gene with universal $16 \mathrm{~S}$ rRNA PCR forward primer (5'-AGAGTTTGATCTGGCTCAG-3') and reverse primer ( $5^{\prime}$-AAGGAGGTGTCCACC-3') was used for amplification. PCR reaction was performed in the thermal cycler (Bio-rad) using the following conditions: initial denaturation of $5 \mathrm{~min}$ at $94^{\circ} \mathrm{C}$, followed by 35 cycles consisting of $30 \mathrm{~s}$ at $94^{\circ} \mathrm{C}$ (denaturation), $20 \mathrm{~s}$ at $58^{\circ} \mathrm{C}$ (annealing) and $1 \mathrm{~min} 30 \mathrm{~s}$ at $72^{\circ} \mathrm{C}$ (extension) and final extension of $15 \mathrm{~min}$ at $72^{\circ} \mathrm{C}$ (Table 3 ).

DNA sequencing and sequence analysis: The PCR products were analysed by $1.2 \%$ agarose gel electrophoresis; amplified products in the gel were cut by clean scalpel, purified using Quigen quick PCR purification kit and DNA was sequenced (Xcleris, India). BLAST

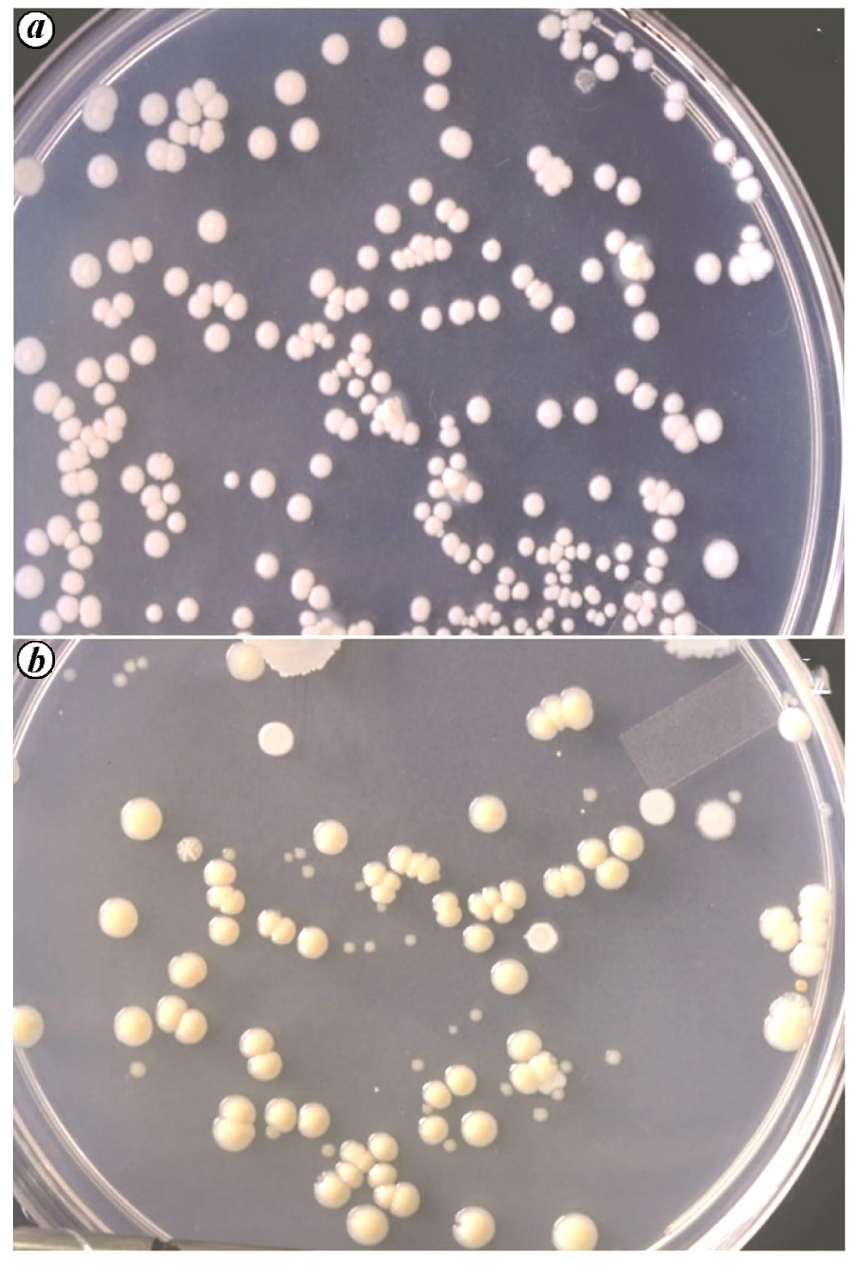

Figure $5 \boldsymbol{a}$ and $\boldsymbol{b}$. Bacterial colonies from calcite samples of the monument.

CURRENT SCIENCE, VOL. 116, NO. 11, 10 JUNE 2019 


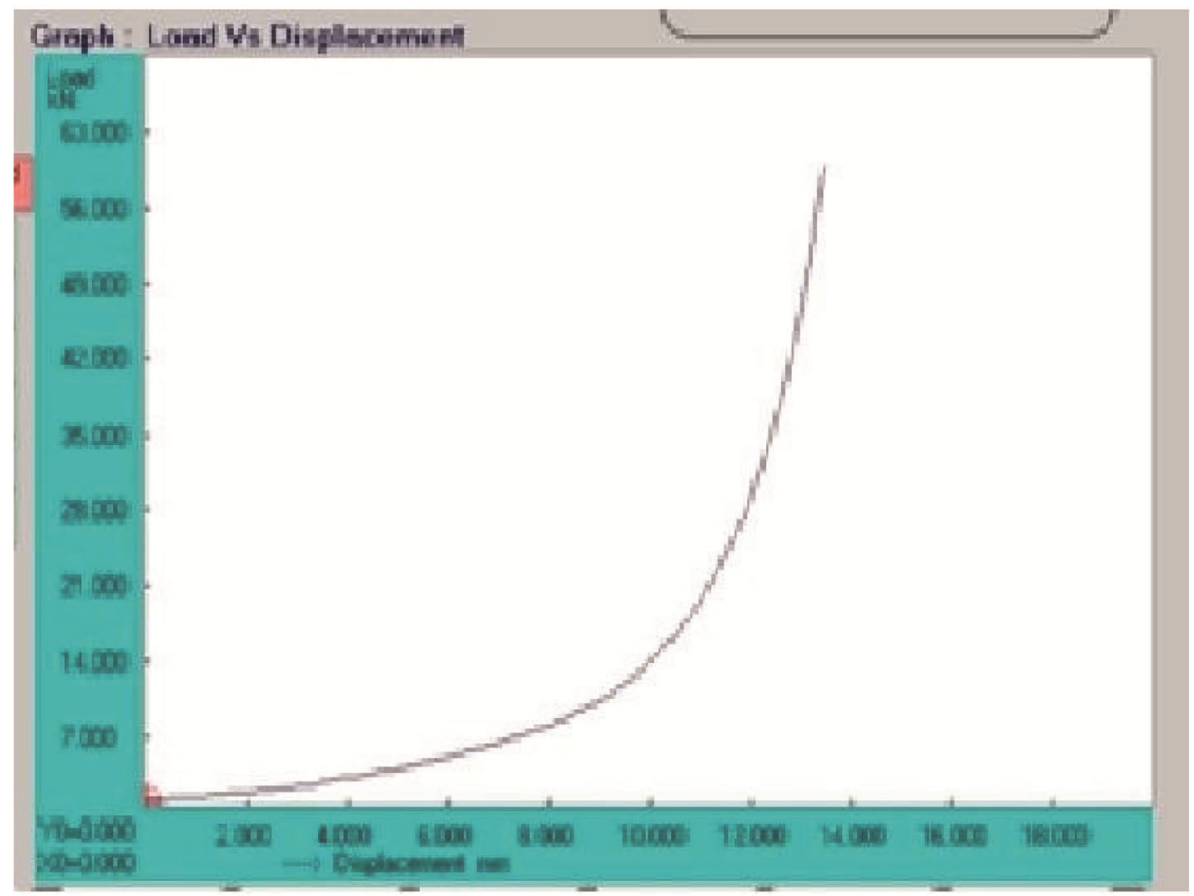

Figure 6. Strength gauge measurement of calcite sample.

Table 3. Identification of bacterial isolates

\begin{tabular}{ll}
\hline Isolates & \multicolumn{1}{c}{ Bacteria } \\
\hline $\mathrm{S} 1$ & Bacillus $\mathrm{sp}$. \\
$\mathrm{S} 2$ & Aquamicrobium $\mathrm{sp}$. \\
$\mathrm{S} 3$ & Agromyces indicus \\
$\mathrm{S} 4$ & Arthobacter sp. \\
\hline
\end{tabular}

algorithm was used in the analysis of DNA sequences and homology.

\section{Mechanical properties}

Mechanical properties of the leached and hardened calcite were measured with a universal testing machine (UTE100). For determination of comprehensive strength, two hardened calcite samples were selected. For the first test a calcite sample of $78,000 \mathrm{~mm}^{2}$ cross-section area was selected to determine comprehensive strength (Figure 6).

\section{XRD measurement}

X-ray diffraction analysis is commonly used to determine the reticular plane and crystalline structure of samples. The XRD spectrum recorded was in the $2 \theta$ region from $5^{\circ}$ to $120^{\circ}$ with peaks characteristics of $\mathrm{CaCO}_{3}$ which can be attributed to JCPDS file 040637 (Figure 7). The crystal system was hexagonal, rhombo-centred with space group of R3C9 (167) and cell parameters of $a=5.35$ and $c=16.80$. XRD spectrum was recorded using a Phillips 2404, Holland X-ray diffraction machine with a graphite monochromator and $\mathrm{CuK} \alpha$ radiation.

\section{SEM and FTIR analysis}

Morphology and size of the crystals and microorganism were analysed by SEM at different magnifications. The SEM photomicrograph of the bulk plaster (Figure 8) was obtained with the help of SEM (FEI ESEM Quant 200, USA) at a range of magnifications to identify the components of deposits. FTIR spectra analysis of calcite deposits was also carried out for their characterization. For this, a small quantity of calcite deposit was mixed with $\mathrm{KBr}$; the pellet was freshly prepared and used. The FTIR spectra were obtained in the regime $4000-550 \mathrm{~cm}^{-1}$ using Agilent 600 series FTIR spectroscopy equipped with nitrogen-cooled MCT detector. The spectra were obtained from different areas of the sample (Figure 9).

\section{Results}

Table 1 lists the major chemical oxides identified in the samples. For this study, three analyses were carried for each of the samples and average of the data was taken for consideration. From the chemical analysis data of the original lime core (sample 1), it was observed that the mortar used in the construction of the Salabat Khan Tomb 


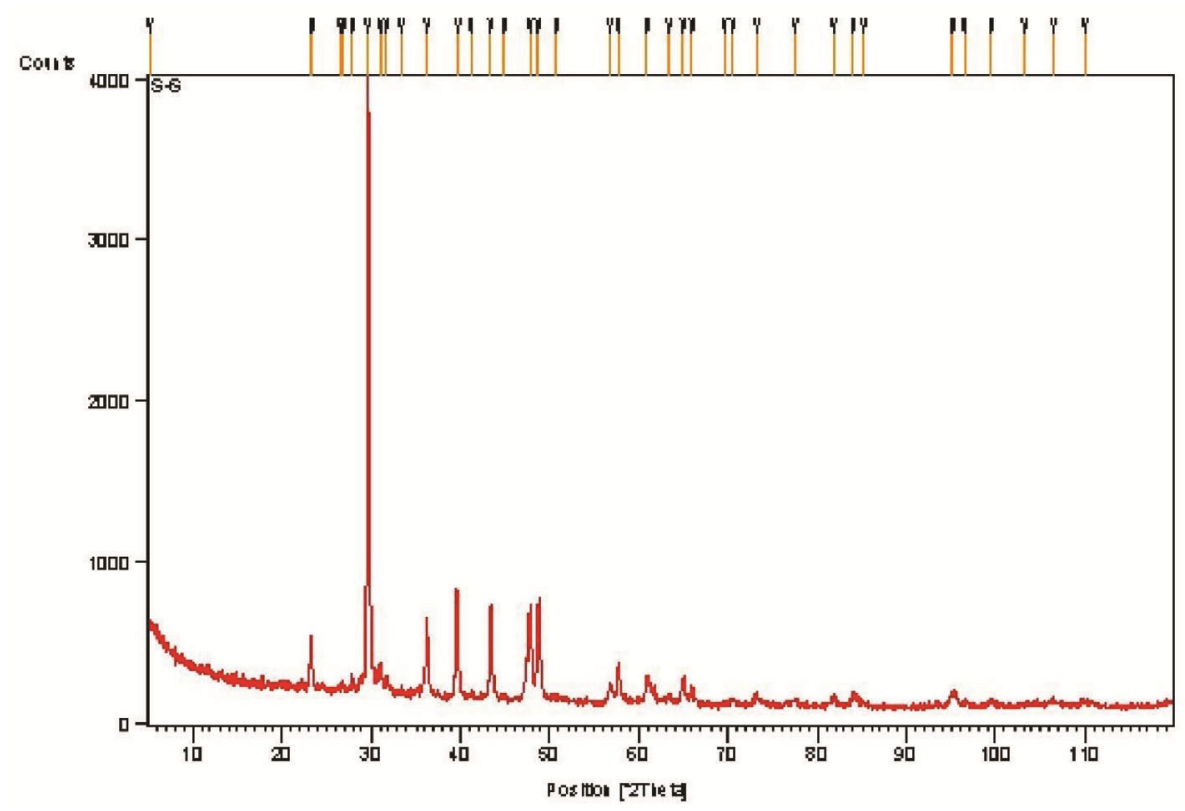

Figure 7. X-ray diffraction spectrum of calcite sample.

was a dolomitic lime ( $\mathrm{MgO} 8.65 \%)$ and that the mortar was of poor quality. Besides, addition of aggregate in lime to provide strength and durability to the mortar was just negligible $\left(\mathrm{SiO}_{2}-2.4 \%\right)$. From the chemical composition data of sample 1, it can be deduced that almost pure dolomitic lime with its impurities has been used in the construction of the Salabat Khan Tomb. The addition of less aggregate in the mortar works has also been confirmed by SEM images of sample 1. Phenolphthalein gives colour when mixed in the lime solution, indicating that some of the limes still not carbonate and are in the form of hydroxides. As the lime mortar has not sufficiently carbonated, there is a probability of its leaching when rainwater seeps through the roof of the structure, as in the case of this monument. During rainy season, dissolved lime oozes out either on the fresh stone surface or on the previously deposited leached-out calcite surface, which can be well observed on the monument surface. It was also observed that magnesium salts being more soluble preferably leached out from the parent mortar. However, magnesium and calcium displacement reactions come into play here resulting a decrease in magnesium content in the leached-out materials and simultaneously proportionate increase in the calcium ions in the dried deposits. Such types of reaction are common in soil science/ groundwater survey. In the deposited material there was increase of phosphate due to bacterial dead cells. It must be noted that increased $\mathrm{Ca}^{2+}$ ions and phosphate cause higher precipitation of calcite due to microbial activity. Traces of silica, iron, zinc and copper observed in the sample are due to exterior contamination of dirt and dust from air.

Table 2 shows results of petrological analysis of the samples. It can be observed that the deposits mainly consist of calcite with minor minerals of quartz and biotite. The four isolated potential organisms were identified by $16 \mathrm{~S}$ rRNA gene sequencing. The $16 \mathrm{~S}$ rRNA region was amplified as a single amplicon with $16 \mathrm{~S}$ primer set. The homology of the 16S rRNA sequence was matched to the NCBI database. Depending on the percentage of matches and total mismatches, the strains were identified (Table 3).

The load versus displacement curve (Figure 6) indicates that the calcite particles compress in a relatively linear manner with increase in load at the initial stage and then inflection points appear in the region $2-8 \mathrm{~mm}$, where significant changes occur in displacement indicating that the particles can no longer withstand the load and suddenly deform by a large amount. With an increase in load up to $60.150 \mathrm{kN}$, the material becomes brittle at a maximum displacement of $13.5 \mathrm{~mm}$. Calcite has a comprehensive strength of $0.001 \mathrm{kN} / \mathrm{mm}^{2}$. Figure 6 shows comprehensive strength graphs for calcite. In the second measurement, 24,012 $\mathrm{mm}^{2}$ cross-sectional area was considered for comprehensive strength determination. For this analysis, maximum force of $17.850 \mathrm{kN}$ was applied. The sample showed a comprehensive strength of $0.001 \mathrm{kN} / \mathrm{mm}^{2}$ at this instant as well. This indicates that comprehensive strength throughout the length and width of the leached-out calcite is the same, irrespective of the area considered for analysis. A continuous rise in the graph can be seen even after failure of the material, as calcium has a natural tendency to agglomerate on fracturing under compression.

The XRD results showed that the bacteria mainly precipitated calcite as maximum number of calcite peaks were observed (Figure 7). XRD analysis also showed that the carbonate formation from which the microorganism 


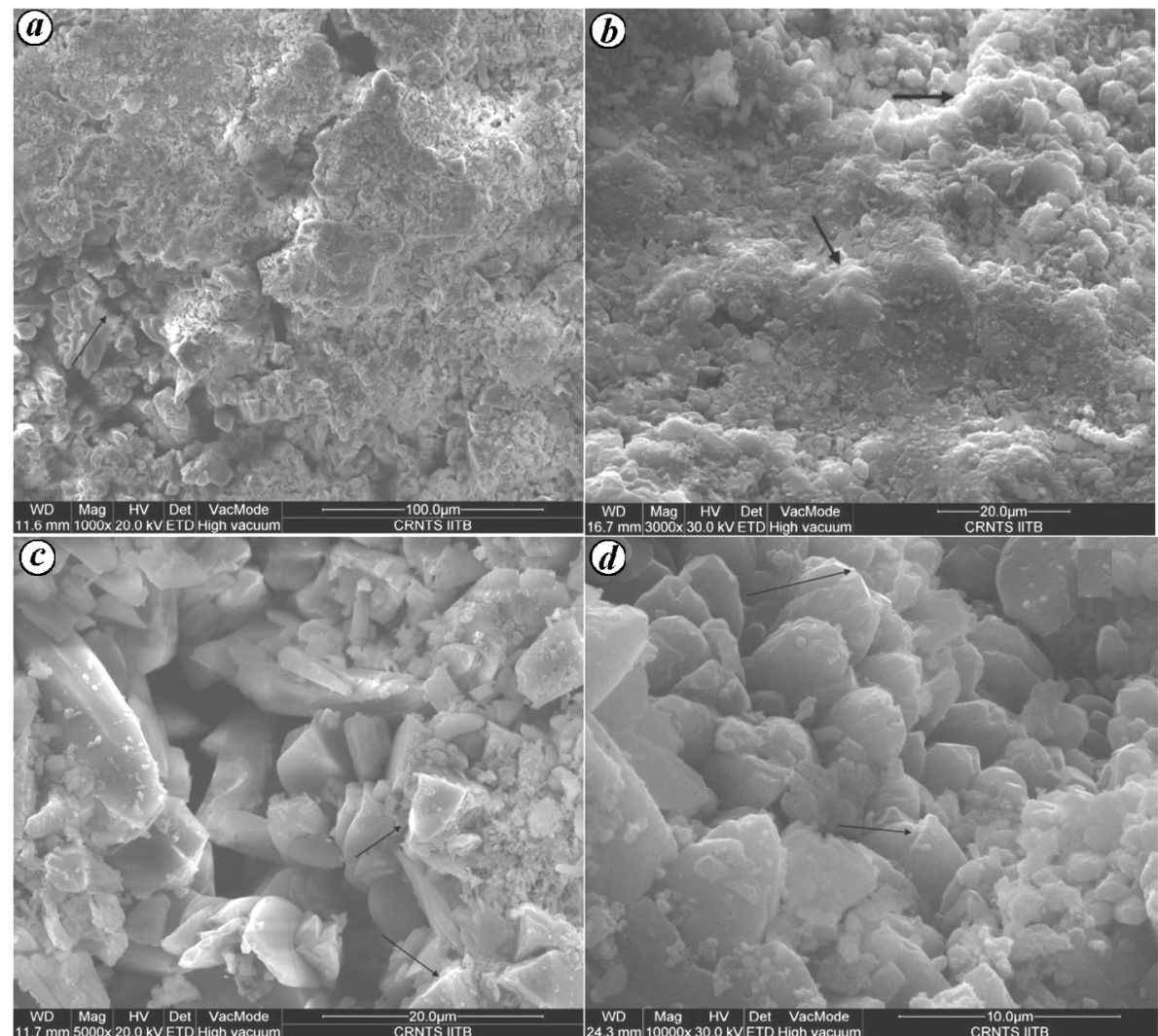

Figure $8 \boldsymbol{a}-\boldsymbol{d}$. SEM images of calcite sample at $1000 \times, 1000 \times, 5000 \times$ and $10000 \times$ magnification.

was isolated was from pure calcite. Bacteria served as nucleation sites during mineralization process. This was confirmed by the presence of crystalline calcium carbonate associated with bacterial colonization.

SEM photomicrographs of calcite deposit are shown in Figure $8 a-d$ for different magnifications. From the SEM image of sample 1 (Figure $8 a$ ), it is observed that the binding mortar used is almost pure lime with little aggregate. The photomicrograph also shows tangled calcite needles giving a rather rough surface. The pore size of the mortar sample is uniform but at some points, few fine cracks have developed. It is observed from SEM images of samples 2 and 3 (Figure $8 b-d$ ) at different magnifications that after bio-deposition, the surface has strongly modified and formed a less rough surface producing smooth calcite layers. SEM analysis of microbial samples shows distinct rhombohedral-shaped calcite crystals with rounded bacterial spores. Ovoid bacterial bodies $(2 \mu \mathrm{m}$ long and $0.5 \mu \mathrm{m}$ wide) due to precipitation of bacterial membrane (especially carbonate mineralization) have created a relief on the smooth surface. Moreover, crystal growth is observed after bio-deposition along with numerous cracks. The presence of calcite in the form of calcium carbonate can be confirmed with high amount of calcium in all the bacterial samples. While examining the calcite crystals using SEM, it was observed that virtually all the crystals included pits and depressions that matched the structure of precipitating bacteria both in terms of size and morphology. These cracks are common features of biofilms observed by SEM. In case of FTIR spectra (Figure 9), generally, the 1409 and the $872 \mathrm{~cm}^{-1}$ peaks are due to $-\mathrm{OH}$ bending vibration and $-\mathrm{OH}$ out-of-plane bending vibration respectively. In the white deposit analysed, carbonate peaks were observed at 1400 and $872 \mathrm{~cm}^{-1}$. In the FTIR spectra, small peak was also observed at $711 \mathrm{~cm}^{-1}$, which can be attributed to the methylene $\left(-\mathrm{CH}_{2}-\right)$ rocking vibration. If some microorganisms are present, methylene gas may evolve, and the small peak denotes the presence of microorganism in calcite.

\section{Discussion}

Bio-cementation or bio-grout as an in situ calcium carbonate precipitation is preferable to chemical cemented materials in reducing porosity, permeability of the material, and resistance to weathering. Conservation material cemented chemically is subjected to weathering that leads to increase in porosity, thus altering its mechanical behaviour. In geotechnical engineering, chemical cementation or chemical grout is a process through which voids in sandstone are mostly filled. In the presence of excess calcium ions, in bio-cementation process, carbonates are released by ureolytic bacteria 


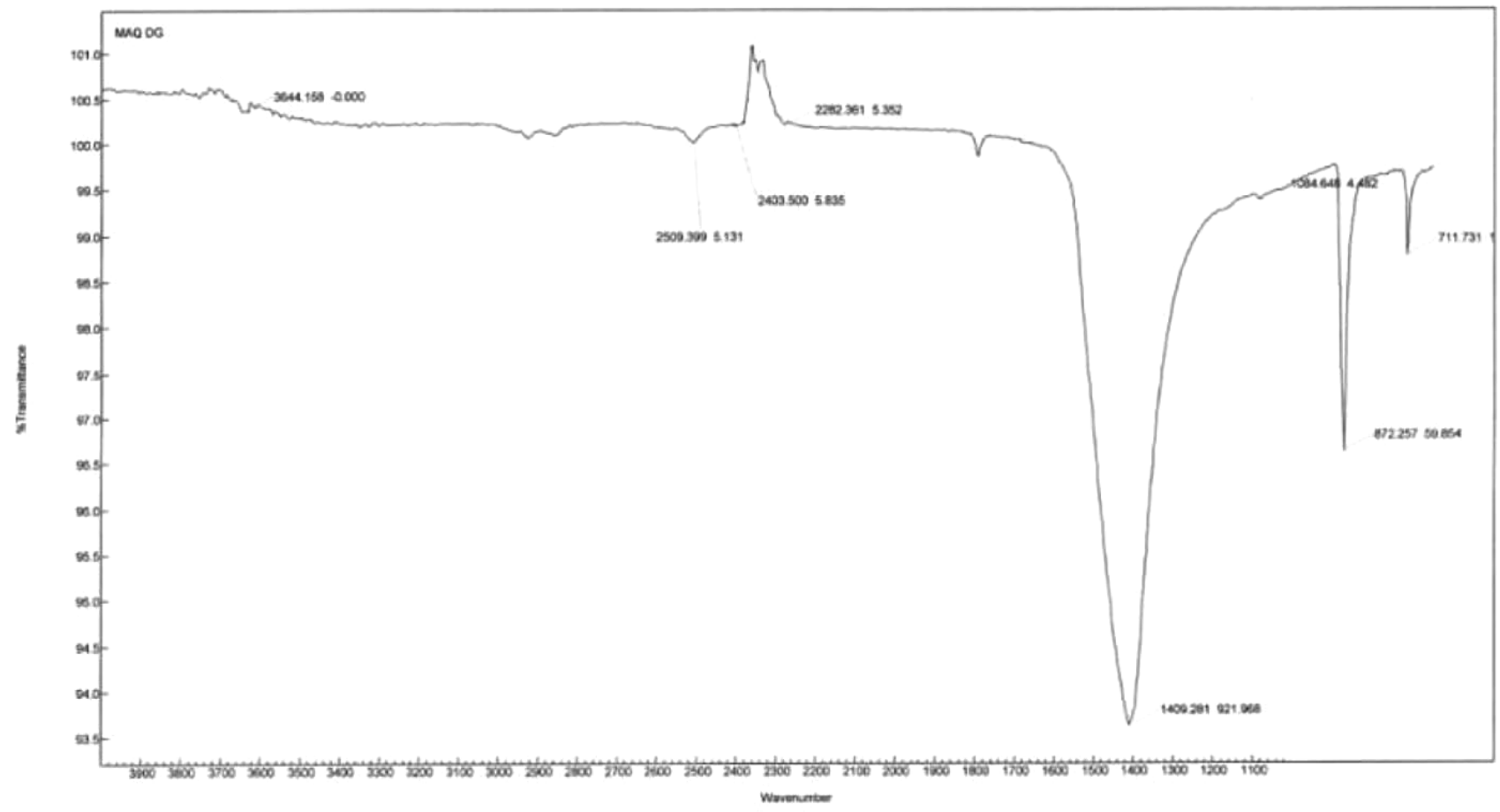

Figure 9. FTIR spectrum of calcite sample.

through urea hydrolysis to form in situ calcite. Calcite, aragonite and vaterite are the three crystals formed by nucleation (same chemical formula but different structure). The most stable form of $\mathrm{CaCO}_{3}$ with single rhombohedral shape is considered to be calcite. Under suitable conditions, calcite can be of commercial use and can result in soil solidification. An innovative technique of remediating cracked structural element has now been advanced by engaging selective microbial plugging process in which calcium carbonate precipitation is promoted by microbial metabolic activities. Research is presently being carried out for the development of calcite precipitation using bacteria and to explore its commercial use. From the various instrumental analyses and microbial tests carried out on the calcite deposits of the Salabat Khan Tomb, the role of bacteria in hardening the deposits on the monument surface can be well visualized.

The isolates were well characterized at the genus level by almost complete $16 \mathrm{~S}$ rRNA gene sequencing. As the monument is lashed by fierce winds with an average wind speed of about 20-25 mph, the deposits also dry quickly. In the summer season when the ambient temperature around the monument is around $42-45^{\circ} \mathrm{C}$, water evaporation from the interior of deposits takes place rapidly and this in turn causes its further hardening. This is one of the reasons for less water content in the deposited material during the analysis. This has caused cementing of calcite and further difficulty in its removal from the stone surface of the tomb during cleaning.
Therefore, the naturally occurring process of calcite precipitation on the basaltic stone surface of the Salabat Khan Tomb is not desirable. The removal of whitish patches is necessary for aesthetic presentation of the monument. Recently, structural conservation measures in the form of water tightening on the roof of the monument were carried out to stop ingress of water into the interior walls. The work was carried out using lime aggregate by filling up all the open joints and damaged parts of the old roof of the monument. It is hoped that after this conservation measure water ingress to the monument will not occur. At this stage, it is also essential to remove calcite deposited in patches from the exterior surface. Accordingly, its removal by physico-chemical process was extensively carried out with great care and precaution. Diluted acetic acid solution $(3 \%-5 \%)$ was used at first to loosen the calcite deposits. All necessary precautionary measures were taken during the process. It was observed that at some points the repeated deposits had made the surface $4-5 \mathrm{~cm}$ thick and at other point the thickness observed was less than 1-2 mm. During the process of loosening the deposits by acetic acid, time of reaction was adjusted according to thickness of the deposits. After this treatment, the loosened calcite was slowly removed with a soft brush and nebulized water. The removed calcite deposits with bacterial cells within can also find many commercial uses, such as purification of wastewater, culturing of bacteria or hardening beneath the building. However, calcite precipitation through microbial process 
on the stone surface of limestone/marble monuments can be of immense value in their preservation.

\section{Conclusion}

Although bio-cementation is a desirable natural process with immense commercial applications, the same is unsuitable in case of the Salabat Khan Tomb. However, the removed calcite deposits how can be unleashed in the field of geotechnical revolution by bio-cementation and can be used commercially. The process can also be utilized in the protection and conservation of many marble/limestone monuments.

1. Boquet, E., Boronat, A. and Ramos-Cormenzana, A., Production of calcite (calcium carbonate) crystals by soil bacteria is a general phenomenon. Nature, 1973, 246, 527.

2. Castanier, S., Le Métayer-Levrel, G., Orial, G., Loubière, J.-F. and Perthuisot, J.-P., Bacterial carbonatogenesis and applications to preservation and restoration of historic property. In Of Microbes and Art, Springer, Boston, MA, 2000, pp. 203-218.

3. Le Métayer-Levrel, G., Castanier, S., Orial, G., Loubière, J.-F. and Perthuisot, J.-P., Applications of bacterial carbonatogenesis to the protection and regeneration of limestones in buildings and historic patrimony. Sediment. Geol., 1999, 126(1-4), 25-34.

4. Hammes, F., Boon, N., Clement, G., de Villiers, J., Siciliano, S. and Verstraete, W., Molecular, biochemical and ecological characterisation of a bio-catalytic calcification reactor. Appl. Microbiol. Biotechnol., 2003, 62, 191-201.

5. Stocks-Fischer, S., Galinat, J. K. and Bang, S. S., Microbiological precipitation of $\mathrm{CaCO}_{3}$. Soil Biol. Biochem., 1999, 31, 1563-1571.

6. Rivadeneyra, M. A., Ramos-Cormenzana, A., Delgado, G. and Delgado, R., Process of carbonate precipitation by Deleya halophila. Curr. Microbiol., 1996, 32, 308-313.

7. Fujita, Y., Ferris, F. G., Lawson, R. D., Colwell, F. S. and Smith, R. W., Subscribed content calcium carbonate precipitation by ureolytic subsurface bacteria. Geomicrobiol. J., 2000, 17(4), 305-318.

8. Smith, P. T., King, A. D. and Goodman, N., Isolation and characterization of urease from Aspergillus niger. Microbiology, 1993, 139, 957-962.

9. Bachmeier, K. L., Williams, A. E., Warmington, J. R. and Bang, S. S., Urease activity in microbiologically-induced calcite precipitation. J. Biotechnol., 2002, 93, 171-181.

10. Mobley, H. L., Island, M. D. and Hausinger, R. P., Molecular biology of microbial ureases. Microbiol. Rev., 1995, 59, 451-480.

11. Baskar, S., Baskar, R., Mauclaire, L. and McKenzie, A. J., Microbially induced calcite precipitation in culture experiments: possible origin for stalactites in Sahastradhara caves, Dehradun, India. Curr. Sci., 2006, 90(1), 58-64.

12. Baskar, S., Baskar, R., Lee, N. and Theophilus, P. K., Speleothems from Mawsmai and Krem Phyllut caves, Meghalaya, India: some evidences on biogenic activities. Environ. Geol., 2008, 57, 1169-1186.

13. Cañveras, C., Sanchez-Moral, S., Sloer, V. and Saiz-Jimenez, C., Microorganisms and microbially induced fabrics in cave walls. Geomicrobiol. J., 2001, 18(3), 223-240.
14. Laiz, L., Groth, I., Gonzalez, I. and Saiz-Jimenez, C., Microbiological study of the dripping waters in Altamira cave (Santillana del Mar, Spain). J. Microbiol. Methods, 1999, 36, 129-138.

15. Groth, I., Vettermann, R., Schuetze, B., Schumann, P. and SaizJimenez, C., Actinomycetes in karstic caves of northern Spain (Altamira and Tito Bustillo). J. Microbiol. Methods, 1999, 36, $115-122$.

16. Laiz, L. et al., Microbiology of the stalactites from Grotta dei Cervi, Porto Badisco, Italy. Int. Microbiol., 2000, 3, 25-30.

17. Barton, H. A. and Northup, D. E., Geomicrobiology in cave environments: past, current and future perspectives. J. Cave Karst Stud., 2007, 69, 163-178.

18. Ehrlich, H. L., Geomicrobiology, CRC Press, 2002, Fourth edn.

19. Vies, A., Biomineralization: cell biology and mineral deposition. Science, 1990, 247(4946), 1129-1131.

20. Castanier, S., Le Métayer-Levrel, G. and Perthuisot, J.-P., Ca-carbonates precipitation and limestone genesis - the microbiogeologist point of view. Sediment. Geol., 1999, 126(1-4), 9-23.

21. Ercole, C., Cacchio, P., Botta, A. L., Centi, V. and Lepidi, A., Bacterially induced mineralization of calcium carbonate: the role of exopolysaccharides and capsular polysaccharides. Microsc. Microanal., 2007, 13, 42-50.

22. Riding, R., Microbial carbonates: the geological record of calcified bacterial-algal mats and biofilms. Sedimentology, 2000, 47, 179-214.

23. Tiano, P., Biagiotti, L. and Mastromei, G., Bacterial bio-mediated calcite precipitation for monumental stones conservation: methods of evaluation. J. Microbiol. Meth., 1999, 36, 139-145.

24. Perrier, R., Les roches ornementales, Pro Roc, 2004.

25. Černý, R., Drchalová, J., Hošková, S. and Toman, J., Methods for evaluation of water-proofness quality and diffusion properties of coating materials. Constr. Build. Mater., 1996, 10, 547-552.

26. Kahoui, R. E. L., Adolphe, J.-P. and Daudon, M., Identification of Early bacillus-induced crystals in vitro using Fourier transform infrared spectroscopy. Microbes Environ., 2000, 15, 161-171.

27. Le Métayer-Levre, G., Castanie, S., Orial, G., Loubière J.-F. and Perthuisot, J.-P., From carbonatogenesis concepts to bacterial regeneration of limestones (microbial lifting). In IAS-ASF-IGCP 380 International Workshop on Microbial Mediation in Carbonate Diagenesis, Chichilianne 22-24/09/97, Abstract Book ASF, Paris, 1997, vol. 26.

28. Prabhakara, R., Biomineralisation of calcium carbonate by different bacterial strains and their application. Int. J. Adv. Eng. Technol., 2013, 6, 202-213.

29. Carpinteri, A. and Fracture, I. C., In 11 th International Conference on Fracture, Turin, Italy, 20-25 March 2005.

ACKNOWLEDGEMENTS. This study was partly financed by the National Museum Institute, New Delhi. M.S. thanks the Director General, Archaeological Survey of India, Delhi for support. We also thank Prof D. N. Singh (IIT, Mumbai) for help.

Received 13 April 2018; accepted 25 January 2019

doi: $10.18520 / \mathrm{cs} / \mathrm{v} 116 / \mathrm{i} 11 / 1840-1849$ 